\title{
Particulate PhozzyLogic Index for policy makers-an index for a more accurate and transparent identification of critical source areas
}

\author{
Gerold Hepp *, Ottavia Zoboli, Eva Strenge, Matthias Zessner \\ Institute for Water Quality and Resource Management, Technische Universität Wien, Karlsplatz 13/226, 1040, Wien, Austria
}

\section{A R T I C L E I N F O}

\section{Keywords:}

Water pollution

Spatial modeling

PhosFate model

Sediment transport

Watershed management

Fuzzy logic

\begin{abstract}
A B S T R A C T
The identification of critical source areas (CSAs) is a key element in a cost-effective mitigation of diffuse emissions of phosphorus from agricultural soils into surface waters. One of the challenges related to CSAs is how to couple complex, data-intensive fate and transport models with easy-to-use information on field level for management purposes at the scale of large watersheds. To fill such a gap and create a bridge between the two tasks, this study puts forward the new Particulate PhozzyLogic Index (PPLI) based on the innovative combination of the results of a complex watershed model (in this case the PhosFate model) with fuzzy logic. Its main feature is the ability to transform the results of diverse scenarios or even models into a final map showing a catchmentwide ranking of the possibility of high PP emissions reaching surface waters for all agricultural fields. Further, this study enhances the PhosFate model with a new algorithm for the allocation of particulate phosphorus (PP) loads entering surface waters to their sources of origin. This is a basic requirement for the identification of critical PP source areas and in consequence for a cost-effective implementation of mitigation measures. By means of a sensitivity analysis, this study investigates the impacts of storm drains, discharge frequencies and flow directions on the designation of CSAs with the help of present-day scenarios for a case study catchment with an area of several hundred square kilometres. The upfront model calibration exhibits a Nash-Sutcliffe efficiency (NSE) of about 0.95 and a modified Nash-Sutcliffe efficiency (mNSE) of around 0.83. A core result of the sensitivity analysis is that the scenarios at least partially disagree on the identified CSAs and suggest that especially open furrows at field borders have the potential to lead to deviating outcomes. All scenario results nevertheless support the $80: 20$ rule, which states that about $80 \%$ of the phosphorus inputs into the surface waters of a catchment originate from only about $20 \%$ of its area.
\end{abstract}

\section{Introduction}

An innovative aspect of the European Union Water Framework Directive (European Comission, 2000) is the inclusion of economic principles in river basin and water quality management (Martin-Ortega and Balana, 2012). In particular, conservation measures must be evaluated with respect to how cost-effectively they contribute to the achievement of the "good status" of water bodies. The effectiveness and thus the cost-effectiveness of measures, however, is not uniform and strongly depends on the location of their implementation. This non-uniformity exists on different scales and ranges from the national to the local scale and beyond.

In the field of diffuse pollution, one can find the concept of critical source areas (CSAs) on one of the largest scales, i.e. often the field scale. CSAs are commonly defined as those areas within a watershed, which contribute disproportionately to the pollution load in surface waters via one of many possible transport pathways (e.g. Heathwaite et al., 2005; Pionke et al., 2000; Strauss et al., 2007). This concept is especially applicable to particulate-bound pollutants, whose emission into water bodies is primarily driven by soil erosion. Phosphorus is a classic example of such substances. Upon excessive fertilisation, the surplus of phosphorus not taken up by crops becomes almost "fixed" in the soil through processes of sorption, precipitation, immobilisation and mineralisation (Tiessen, 2008).

The transfer of phosphorus strongly bound to particles (particulate phosphorus: PP) via soil erosion and surface run-off into surface waters represents a major environmental concern, due to its eutrophication and water quality impairment potential (Sims and Sharpley, 2005). Differences in e.g. slope, crop cover, agricultural practices and connectivity to streams lead to considerable differences in the extent of contributions to

\footnotetext{
* Corresponding author.

E-mail address: ghepp@iwag.tuwien.ac.at (G. Hepp).
} 
the total PP load reaching water bodies. Usually, only a small portion of a watershed is responsible for the majority of phosphorus inputs into its surface waters (e.g. Kovacs et al., 2012; Strauss et al., 2007; White et al., 2009). Sharpley et al. (2009) state as a rule of thumb that about $80 \%$ of the phosphorus inputs into the surface waters of a catchment originate from only about $20 \%$ of its area. This relationship is also known as the 80:20 rule or the Pareto principle.

An early approach to identify such hotspot areas is the Phosphorus Index (Lemunyon and Gilbert, 1993), which was originally developed in the USA but has found its way to Europe since then (Heathwaite et al., 2003). By now, there exist several modifications and/or localisations of the Phosphorus Index (Buczko and Kuchenbuch, 2007). A general advantage of all of them is that they are simple, easy to communicate and capable of identifying high-risk regions for a cost-effective implementation of emission mitigation measures (Cherry et al., 2008).

The separation of source and transport factors and the incorporation of hydrologic return periods by Gburek et al. (2000) comprises an important modification. Although the Phosphorus Index is still a semi-quantitative tool, especially the Iowa Phosphorus Index tries to approximate biologically available phosphorus loads entering surface waters (Mallarino et al., 2002). Beyond that, with its stronger physical basis, the Swedish Phosphorus Index requires more input data and is not as easy to calculate as other Phosphorus Indices (Buczko and Kuchenbuch, 2007).

This leads us to another approach to identify CSAs: semi-empirical/ conceptual, spatially distributed soil erosion and phosphorus transport modelling. While this approach usually requires even more input data and higher calculation efforts, it can be expected to provide more accurate results than the Phosphorus Index approach, due to its improved quantitative basis. It generally represents a good compromise between solely empirical and process based models (Cherry et al., 2008). Examples are the WaTEM/SEDEM (Onnen et al., 2019; Van Oost et al., 2000; Van Rompaey et al., 2001; Verstraeten et al., 2002) and PhosFate (Kovacs et al., 2008, 2012) models.

However, as it is well pointed out by Ghebremichael et al. (2013), one major drawback of this approach is that it is not outright clear how to translate model results into catchment-wide risk assessments on field-level, i.e. at the lowest spatial unit managed by farmers and thus the level at which conservation measures can actually be applied. One problem with linking results of hydrological models to prioritisation at field scale is that field and farm boundaries do not usually coincide with hydrological boundaries. This gap makes the outcome of complex catchment-scale models of limited application and use for policy makers, farmers and practitioners involved in agri-environmental programmes. We put forward that fuzzy logic could be the key to both overcome this shortage and to reduce vagueness in identifying CSAs.

Fuzzy logic was developed in the mid-sixties of the twentieth century and is based on fuzzy sets (Zadeh, 1965). Later it was developed further into a theory of possibility (Zadeh, 1978). As possibility theory and Phosphorus Index surprisingly share some very basic ideas, we hypothesise that the potential of phosphorus loss or movement into surface waters from a certain site as it is used by the Phosphorus Index is conceptually related to possibility theory. It is yet lacking its theoretical foundation in mathematics. Hence, why it is called an index.

While fuzzy logic has been previously applied successfully to, for example, river quality (e.g. Lermontov et al., 2009; Liou et al., 2003), groundwater quality (e.g. Rebolledo et al., 2016; Vadiati et al., 2016) and landslide susceptibility (e.g. Champati ray et al., 2007; Pourghasemi et al., 2012; Tien Bui et al., 2012) analyses, to our knowledge it has not been used in the context of the identification of CSAs so far.

The main research goal of this study is to develop a novel semiempirical "index" for PP based on the combination of spatially distributed models, i.e. PhosFate in our case, with fuzzy logic. As a prerequisite to this, we aim to completely redesign and enhance the model's existing algorithm for allocating the PP emissions actually reaching surface waters to their respective source areas so that conservation of mass is guaranteed under all circumstances. Furthermore, the study conducts a sensitivity analysis to determine the impacts of selected uncertain input data (flow directions) and model parameters (discharge frequencies) on the designation of CSAs in the form of present-day scenarios for a case study catchment with an area of several hundred square kilometres.

\section{Material and methods}

\subsection{Case study catchment}

The present study was conducted on the catchment of the river Pram in the north-western part of the Austrian federal state of Upper Austria. According to Zessner et al. (2011), erosion from agricultural land is its only relevant source of diffuse PP emissions. The catchment predominantly belongs to the geologic formation Molasse basin and is approximately $380 \mathrm{~km}^{2}$ in size. Only some small parts in the north and north-east belong to the crystalline Bohemian Massif. Various types of loam with silt loam being the most prominent (nearly 50\% of the catchment area) dominate its soil surface. Clay is only dominant in about $5 \%$ of the area and sandy soils are not present at all.

The elevation of about $300 \mathrm{~m}$ a. s. 1. at the mouth of the river in the north-west gradually rises to about $800 \mathrm{~m}$ a. s. 1 . in the south. Annual precipitation shows a similar gradient ranging from roughly $900 \mathrm{~mm}$ to around $1200 \mathrm{~mm}$. The catchment's major land use type is agricultural land covering approximately $70 \%$ of the area and can be further divided into about $45 \%$ arable land and $25 \%$ grassland. Other important land use types are forests and settlements, which sum up to about $20 \%$ and almost $10 \%$ of the area respectively. Winter grains are cultivated on approximately $40 \%$ and maize on approximately $30 \%$ of the mostly hilly arable land. Table 1 lists a few additional catchment properties.

\subsection{PP emission and transport modelling}

\subsubsection{The PhosFate model}

Originally created by Kovacs et al. (2008, 2012), the semi-empirical, spatially distributed phosphorus emission and transport model PhosFate was recently extended by Hepp and Zessner (2019) with a module capable of taking into account storm drains at road embankments. It models erosion with the help of the (R)USLE (Renard et al., 1997; Schwertmann et al., 1987; Wischmeier and Smith, 1978) making use of a raster GIS data based single (D8) flow algorithm version of the slope length factor (Desmet and Govers, 1996). The PP emission part of the model then combines the erosion with the PP content of the top soil and a local enrichment ratio of each raster cell in order to calculate local gross PP emissions (Kovacs, 2013).

$\mathrm{PP}$ retention in turn is computed via an exponential function of the cell residence time and a mass balance equation including terms for the inflowing PP load, the local gross PP emission and the local as well as the transfer PP retention. The hydraulic radius, among others, is a requirement for the calculation of the cell residence time and itself involves model parameters related to discharge frequency (Kovacs, 2013). With the channel as well as overland PP deposition rates and the PP transfer coefficient of the storm drains model extension, PhosFate features three potential calibration parameters.

Table 1

Additional properties of the case study catchment.

\begin{tabular}{lrrrrrr}
\hline & Min. & 1st Qu. & Median & Mean & 3rd Qu. & Max. \\
\hline Slope $^{\mathrm{a}}$ in \% & 0.00 & 4.59 & 8.41 & 10.22 & 13.50 & 241.23 \\
Discharge $^{\mathrm{b}}$ in $\mathrm{m}^{3} \mathrm{~s}^{-1}$ & 0.94 & 1.87 & 2.68 & 4.58 & 4.23 & 117.00 \\
${\text { Field size in } 10^{4} \mathrm{~m}^{2}}^{0.01}$ & 0.36 & 0.90 & 1.60 & 2.02 & 28.16 \\
\hline
\end{tabular}

a Based on a DEM with $10 \times 10 \mathrm{~m}$ resolution covering the whole catchment area.

b Period 2008 to 2013 of the gauge 204 867, Pramerdorf/Pram close to the outlet with a catchment area of approx. $340 \mathrm{~km}^{2}$ (BMLFUW, 2015). 


\subsubsection{Revised allocation algorithm}

One major output of PhosFate is the calculation of PP cell loads via an allocation algorithm. The PP cell loads describe the amount of local PP emissions actually reaching surface waters, i.e. the PP cell load of a single cell represents its local PP emission minus the cumulated amounts of retention taking place in all of its downstream cells (Kovacs, 2013). Since the original allocation algorithm of the PhosFate model based on transmission coefficients was developed for larger cell sizes (e.g. $100 \times$ $100 \mathrm{~m}$ resolution) than used in this study $(10 \times 10 \mathrm{~m}$ resolution), it was necessary to revise it. A major drawback of the original algorithm is that conservation of mass is not guaranteed in every single cell, but only on the level of zero-order catchments.

The original algorithm requires a single top-down computation starting with the lowest and finishing with the highest flow accumulations. Its results are the PP retentions as well as transports. The revised algorithm builds on this computation and adds an additional bottom-up computation starting with the highest and finishing with the lowest flow accumulations to it. Its results are the PP cell loads for which the local net PP emissions calculated as local PP emissions minus PP retentions constitute the upper PP cell load limits.

This latter computation in turn involves the calculation of PP cell transfers. These are the cumulated amounts of PP entering a cell from upstream cells, which are transferred through the cell and actually reach a surface water (again minus the cumulated amounts of retention taking place in all of its downstream cells). The complete bottom-up computation thus consists of cycles of the following steps, which, however, are executed for overland cells only:

1. Initialising an intermediate cell load either as the transported amount of PP entering a surface water (riparian cells - first cycle) or as the apportioned cell transfer in the last step of the previous cycle (all other cells - subsequent cycles).

2. Initialising an intermediate cell transfer by setting it equal to the previously initialised intermediate cell load.

3. Updating the intermediate cell load by multiplying it with the ratio of the local and the local plus the sum of the inflowing PP transports.

4. Setting the final cell load utilising the local net PP emission as upper limit (minimum of the previously updated intermediate cell load and local net PP emission).

5. Calculating the cell load carry-over as the maximum of the intermediate cell transfer minus the final cell load and zero.

6. Setting the final cell transfer to the previously calculated cell load carry-over.

7. Weighted apportioning of the cell load carry-over to the inflowing cells utilising their PP transports as weights.

\subsubsection{Coupling of the PhosFate with the STREAM model}

The STREAM model was designed to simulate overland flow and erosion in agricultural catchments (Cerdan et al., 2002a,b; Le Bissonnais et al., 2005). Yet it does lack the ability to simulate the emission and transport of chemical substances like phosphorus. What makes it appealing from the point of view of phosphorus emission and transport modelling, though, is its capability to simulate a flow network, which accounts for tillage directions among others (Couturier et al., 2013). The effect of tillage direction on flow direction has been thoroughly studied by Souchere et al. (1998); Takken et al. (2001a,b,c) and depends mainly on the angle between tillage direction and topographic slope aspect, topographic slope gradient and surface roughness.

In order to let PhosFate benefit from the last mentioned feature, we coupled both models, i.e. we used version 3.7.1 of the STREAM model to pre-process the flow direction data handed over to PhosFate. For this, we applied a stepwise approach with (i) topographic flow directions only (TOPO scenario), (ii) the sole enforcement of tillage directions on topographic flow directions for arable land (TILL scenario) and (iii) the combined enforcement of tillage directions and open furrows at all field borders (sides as well as headlands, which demonstrates an extreme case) on topographic flow directions for arable land (FURR scenario). Fortunately, field border data was available from a (geo-)database related to the Integrated Administration and Control System (IACS) of the Common Agricultural Policy (CAP) of the European Union (EU) (Hofer et al., 2014).

As tillage directions are an input parameter to the STREAM model, they first had to be derived. This was accomplished by means of minimum bounding rectangles with smallest areas enclosing each field and the assumption that tillage directions are parallel to the longer sides of those rectangles. A sample of 176 fields was then used to compare such derived tillage directions to visually determined tillage directions from orthophotos. In only about $16 \%$ of the cases ( 29 fields), they deviated by more than $\pm 22.5^{\circ}$. Two more required input parameters are the average surface roughness in tillage direction and the average surface roughness perpendicular to tillage direction. These were globally set to $1-2 \mathrm{~cm}$ and $2-5 \mathrm{~cm}$, respectively. Slopes were generally calculated in the direction of the topographic or enforced D8 flow directions.

\subsubsection{Present-day case study scenarios}

Drained roads and storm drains can be a relevant emission pathway into surface waters in Switzerland (Alder et al., 2015; Bug, 2011; Doppler et al., 2012; Prasuhn, 2011; Remund et al., 2021). Hepp and Zessner (2019) came to the same conclusion for Austria and estimated that in the same catchment as examined in this study, about $77 \%$ of all fields upstream to roads are artificially drained by one or more storm drains with a $90 \%$ highest posterior density interval (credible interval, sometimes also called the Bayesian confidence interval) ranging from approximately $54 \%$ to almost $100 \%$. They further performed a plausibility check of the transfer coefficient of the storm drains model extension accounting for retention in roadside ditches, which delivered a result of roughly 0.60 , i.e. $60 \%$ of all PP emissions that enter roadside ditches and subsequently storm drains are reaching surface waters via such bypasses.

With these introductory words said, the three factors used to define the case study scenarios are as follows: (i) transfer coefficients of 0.32 , 0.46 and 0.60 corresponding to $54 \%, 77 \%$ and $100 \%$ of 0.60 (TC0.32, TC0.46, TC0.60), (ii) discharge frequencies of one (T1) and six years (T6) (utilised for the calculation of the hydraulic radius/residence time and in turn PP retention) and (iii) the three described STREAM model flow direction scenarios, namely, TOPO (topographic flow directions), TILL (enforcement of tillage directions) and FURR (tillage directions combined with open furrows at all field borders). So all in all 18 scenarios (three transfer coefficients times two discharge frequencies times three flow direction data sets) were modelled and assessed.

Storm drains at road embankments of almost all asphalt roads were taken into account with the help of the storm drains model extension. A governmental reference routing dataset provided the necessary road data for this (Geoland.at, 2016). The period of the modelled scenarios ranged from the year 2008 to the year 2013. Water quality data of seven water quality gauges (additionally shown in Fig. 6) could be used to calculate mean annual PP river loads using the same methodology as of Hepp and Zessner (2019).

A detailed overview on all input data is provided by Zessner et al. (2016a, 2017). Some other notable datasets nevertheless are (i) the already mentioned (geo-)database related to the IACS of the CAP of the EU contributing detailed information on the cultivated crops, the different factors of the USLE as well as the field borders (Hofer et al., 2014), (ii) a DEM with $10 \times 10 \mathrm{~m}$ resolution, which served as the main input data for the STREAM model, (iii) non-agricultural land use based on the digital cadastre map and (iv) top soil characteristics derived from the digital soil map of Austria. The latter three datasets were supplied by the State Government of Upper Austria. Lastly, data on PP accumulation in top soil was extracted from Zessner et al. (2011, 2016b) and Manning's roughness coefficients from Engman (1986).

Each of the nine T6 scenarios was then calibrated individually under a channel deposition rate of zero utilising the previously calculated 
mean annual PP river loads as targets and the overland deposition rate as the only calibration parameter. This more or less reflects long-term conditions including in-stream phosphorus stock depletion effects caused by major flood events (Zoboli et al., 2015). It can also be considered a rather conservative approach for identifying CSAs, as it generally leads to lower PP loads from cells farther away from surface waters due to higher overland deposition rates. The overland deposition rates of the nine $\mathrm{T} 1$ scenarios were subsequently adopted from the corresponding T6 scenarios thus simulating conditions as if no respective flood/transport event took place in the modelled period of six years. In order to achieve this, the discharge frequency related parameters of the hydraulic radius calculation are altered accordingly (Liu and De Smedt, 2004; Molnár and Ramírez, 1998).

\subsection{Particulate PhozzyLogic Index (PPLI)}

While providing interesting details, a map displaying the PP cell loads with, for example, $10 \times 10 \mathrm{~m}$ resolution is not outright helpful to policy makers, who have to decide where to cost-effectively implement an emission mitigation measure and where not. This information therefore has to be somehow transformed. For this purpose, we first calculate the total absolute PP contributions to surface waters for each field, i.e. the sum of all PP cell loads of each field with the help of zonal statistics and then apply a fuzzy membership function to those results.

\subsubsection{Fuzzy membership function}

A short introduction to fuzzy sets and fuzzy membership functions is given by Robinson (2003). Basically, fuzzy membership functions are functions turning data sets of arbitrary ranges and scales into fuzzy sets consisting solely of values between zero and one, where zero can be translated into "not possible" or not a member of a given set and one into "perfectly possible" or a member of a given set. All other values between zero and one represent a varying degree of possibility or membership in a given set. A value of, for instance, 0.7 thus stands for a higher degree of possibility or membership in a given set than a value of e.g. 0.4.

Possibility must not be confused with probability, even though they share the same value range. While probabilities are estimated based on data as well as certain assumptions and provide confidence intervals, possibility, especially due to the subjective choice of fuzzy membership functions, is less objective. Nonetheless, once one or more fuzzy membership functions have been chosen, possibility is perfectly objective and can even be used to objectively compare expert judgements. This approach is particularly interesting and helpful in a sparse data environment such as in the case of a cost-effective implementation of mitigation measures against PP inputs into surface waters.

The fuzzy membership function we have chosen is the so called fuzzy large membership function. It has the form

$\mu(x)=\frac{1}{1+\left(\frac{x}{p_{2}}\right)^{-p_{1}}}$

where $p_{1}$ is the spread and $p_{2}$ is the midpoint. For the spread, we generally put in one, which makes the shape of the function somewhat similar to that of a logarithmic function, and for the midpoint, we put in a different value for each scenario. These values were calculated so that $80 \%$ of the respective agricultural land received a value of less than 0.5 and $20 \%$ a value of 0.5 or more (Pareto principle, cf. Sharpley et al., 2009). In this way, the $20 \%$ of the total area of agricultural land belonging to the fields with the highest absolute PP inputs into surface waters received a value of 0.5 or more and are therefore what we consider CSAs. Fig. 1 provides examples of fuzzy large membership functions with a midpoint of $4 \mathrm{~kg} \mathrm{yr}^{-1} \mathrm{PP}$ cell load per field and spreads ranging from one to five.

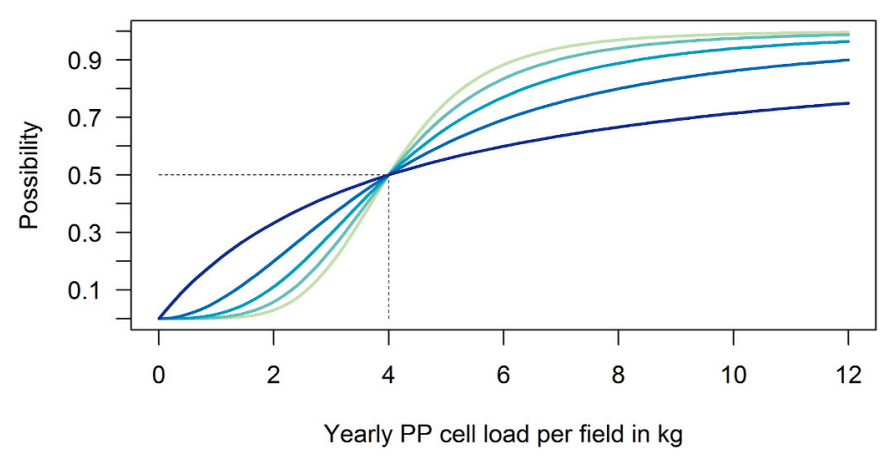

Fig. 1. Examples of fuzzy large membership functions with a midpoint of $4 \mathrm{~kg}$ $\mathrm{yr}^{-1} \mathrm{PP}$ cell load per field and spreads ranging from one (dark blue curve) to five (yellow-green curve). With increasing spread, the function gradually transforms itself from a function with a shape similar to that of a logarithmic function to one with a shape similar to that of a sigmoid function. The black dashed lines shall help illustrate the meaning of the midpoint (possibility of 0.5). (For interpretation of the references to colour in this figure legend, the reader is referred to the Web version of this article.)

\subsubsection{Final Particulate PhozzyLogic Index creation}

While the application of the described fuzzy large membership function to the model results of a single scenario could already be referred to as a fuzzy logic based PP index, this is only the first step, since multiple fuzzy sets can further be overlaid in order to take into account, among others, the uncertainty of input data. A simple technique for this is the so-called convex combination (Dubois and Prade, 1985; Kandel, 1986). In the process of convex combination, each involved fuzzy set can be assigned a weight, which makes it a weighted mean operator with weights adding up to one. Charnpratheep et al. (1997) also propose a modified version of this operator, which sets the overall result to zero in case one or more of the combined fuzzy sets are zero.

As no indication exists that one of our 18 scenarios is more possible than another as far as it comes to a single field and we neither favour one discharge frequency over the other, we used equal weights to overlay the fuzzy sets of all our scenarios with the unmodified convex combination operator in order to create the final PPLI. Using the modified operator does not contribute to the quality of the result in the absence of a knockout criterion.

\section{Results and discussion}

\subsection{STREAM model flow directions}

All in all, the flow direction of about 28\% (approx. 440000 cells) of the arable land were altered by enforcing tillage directions on topographic flow directions (TOPO vs. TILL). While comparing TOPO and FURR results in a somewhat higher share of about 31\% (approx. 500000 cells), comparing TILL and FURR only shows a rather small share of about $8 \%$ (approx. 130000 cells). This is reasonable, since the field borders merely comprise a small portion of the cells representing the arable land of the catchment. Additionally, these shares reveal that about $5 \%$ of the cells were altered two times, first by the TILL and then by the FURR scenario.

Of the roughly 7000 arable fields, nearly 6200 (approx. 88\%) are affected by at least one cell with altered flow directions due to tillage directions and obviously all fields are affected by altered flow directions due to open furrows. An example of the resulting flow directions of the three scenarios is given in Fig. 2.

\subsection{Calibrated overland deposition rates}

Calibration quality of the nine independently calibrated T6 scenarios is altogether very similar. They all exhibit a Nash-Sutcliffe efficiency 


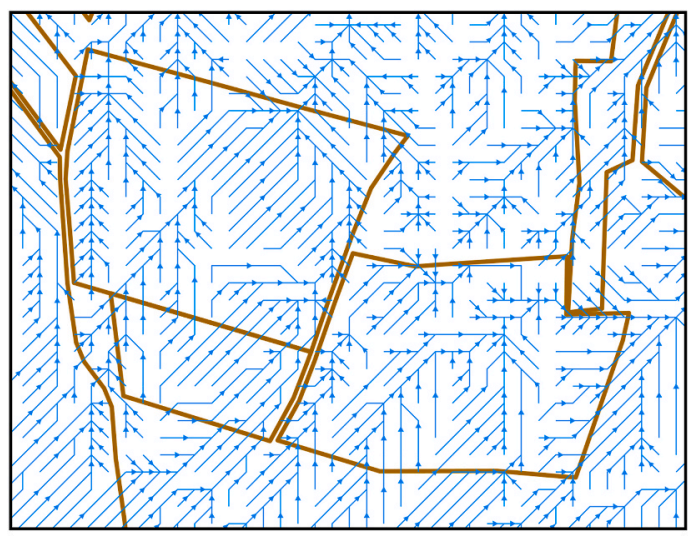

$\square$ Arable field border

Flow directions

$\rightarrow$ - Topographic flow direction
$\rightarrow$ flow direction
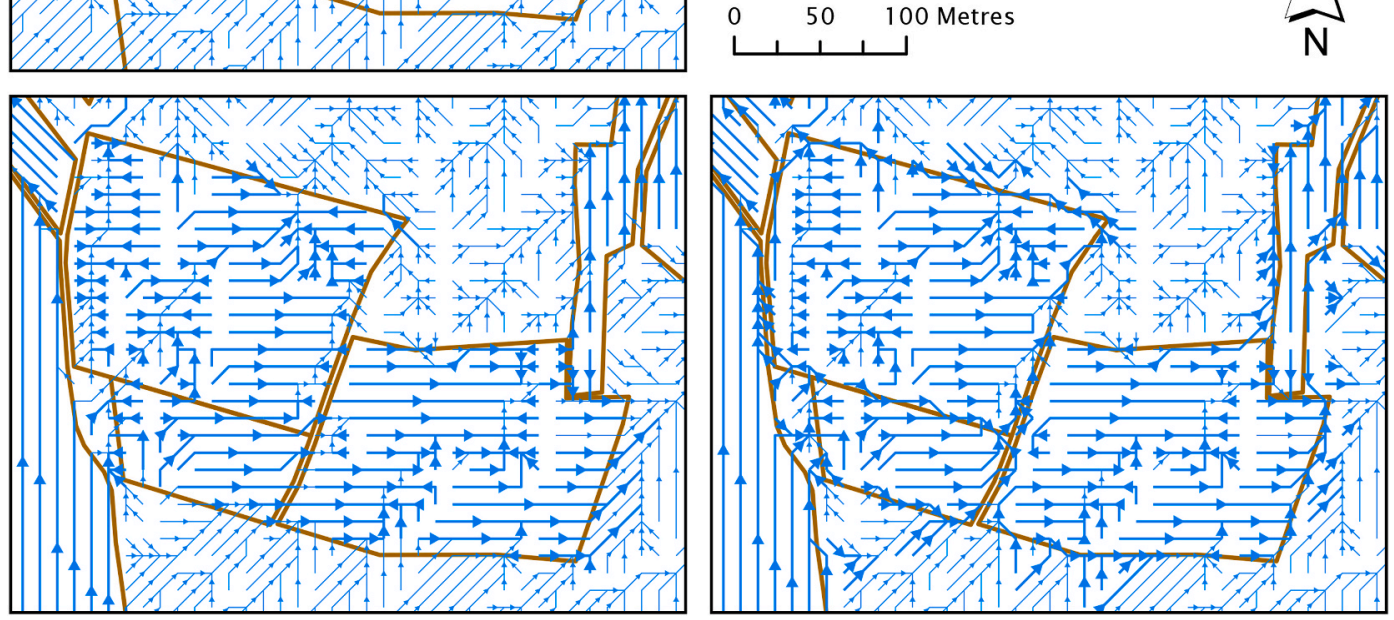

Fig. 2. Example of the resulting flow directions of the TOPO (top left), TILL (bottom left) and FURR scenario (bottom right). Especially the FURR scenario leads to partially more extreme flow accumulations, as it concentrates flow at field borders and limits spillovers to neighbouring fields to cells with a single possible downstream path.

(NSE) of about 0.95, a modified Nash-Sutcliffe efficiency (mNSE) of around 0.83 , a percent bias (PBIAS) of almost zero and a ratio of the root mean square error to the standard deviation of measured data (RSR) of roughly 0.21 (Krause et al., 2005; Moriasi et al., 2007; Nash and Sutcliffe, 1970). Fig. 3 shows the observed and modelled yearly PP loads of

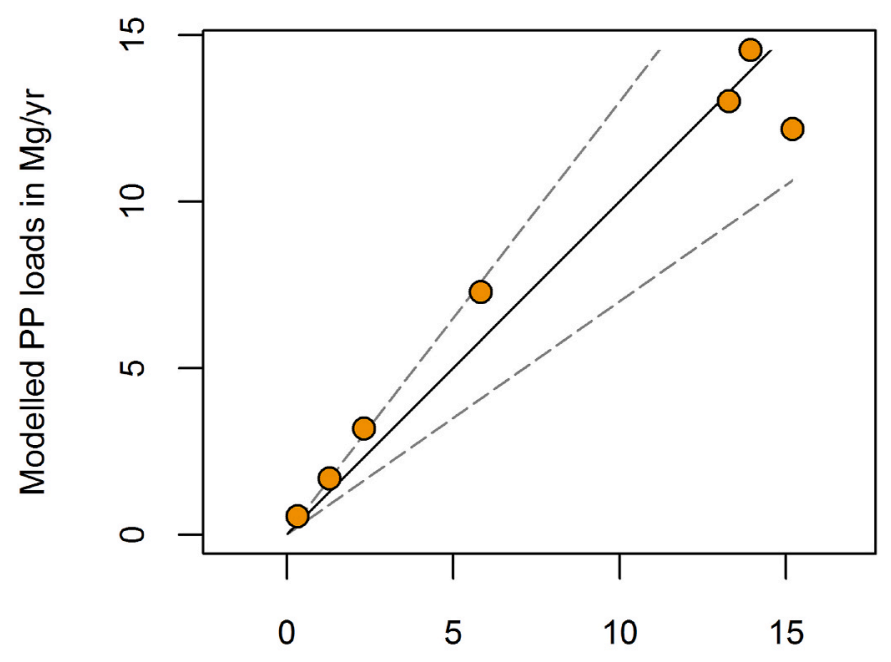

Observed PP loads in Mg/yr

Fig. 3. Observed and modelled yearly PP loads of the representative TC0.46T6-TOPO scenario at the seven water quality gauges along the river Pram. The solid black line represents the 1:1 line and the grey dashed lines 30\% deviations from the 1:1 line. the representative TC0.46-T6-TOPO scenario at the seven water quality gauges along the river Pram. Deviations are bigger for smaller loads, which is also why the mNSE indicates a poorer performance. Poesen (2018) considers scaling up sediment yields from plot to catchment scale one of the main challenges in geomorphological research. Particularly seen in this light, these results are thus very promising.

Calibrated overland deposition rates range from $0.91-1.46 \times$ $10^{-3} \mathrm{~s}^{-1}$ and decrease with lower transfer coefficients $(1.16-1.46 \times$ $10^{-3} \mathrm{~s}^{-1}$ for 0.60 and $0.91-1.21 \times 10^{-3} \mathrm{~s}^{-1}$ for 0.32 ), which is reasonable, as lower inputs into surface waters from fields upstream of roads have to be compensated with higher inputs from fields upstream of surface waters. Generally, the deposition rates of the FURR scenario group are approximately by $0.30 \times 10^{-3} \mathrm{~s}^{-1}$ lower than those of the other two STREAM model scenario groups.

The lower deposition rates of the FURR scenarios may appear counter-intuitive. They are, however, a product of partially lower flow accumulations in the interior of the fields and higher flow accumulations along the field borders. Apparently, the higher transport potential along field borders, which affects rather few cells, does not fully compensate the lower transport potential, which affects the comparatively higher number of cells of field interiors. Thus, the process of calibration has to result in the overall lower deposition rates of the FURR scenario group in order to make up for the gap between the modelled and calculated PP river loads.

\subsection{PP inputs into surface waters}

Catchment-wide PP inputs into surface waters range from about 8.0-8.7 $\mathrm{Mg} \mathrm{yr}^{-1}$ for the $\mathrm{T} 1$ scenario group and 15.9-16.2 $\mathrm{Mg} \mathrm{yr}^{-1}$ for the T6 scenario group. Storm drains at road embankments account for approximately one quarter to almost one half of the PP inputs. The 
respective shares range from $24-29 \%$ for the TC0.32 scenarios, $32-37 \%$ for the TC0.46 scenarios and $39-44 \%$ for the TC0.60 scenarios. This is in line with findings of Prasuhn (2011) whose ten year long field survey resulted in a share of $22 \%$ of the total eroded soil. He also states that about half of the eroded soil was already retained within the borders of the source field though. This share therefore at least has to be doubled in order to account for the input into surface waters alone.

Fields of arable land are predominantly responsible for the catchment-wide PP inputs into surface waters (96.6-98.0\%). Grassland fields $(1.1-1.8 \%)$ and other land use types (0.9-1.6\%) contribute insignificant amounts only; hence, our focus lies on arable fields. Table 2 shows selected percentiles of the sums of yearly PP cell loads per field of arable land for two selected scenarios. The distributions are as expected very skewed. In the case of the TC0.46-T1-TOPO scenario, $70 \%$ of the fields contribute less than $0.5 \mathrm{~kg} \mathrm{yr}^{-1} \mathrm{PP}$ to the total PP emissions into surface waters and even in the case of the TC0.46-T6-TOPO scenario the same percentile amounts to as little as nearly $1.1 \mathrm{~kg} \mathrm{yr}^{-1} \mathrm{PP}$. The amounts of the higher percentiles are increasing rapidly from there on.

Individual yearly PP cell loads and transfers of a small area within the case study catchment are displayed in Fig. 4 for the TC0.46-T6-TOPO scenario. The figure clearly depicts that forests hardly contribute to PP emissions into surface waters, but act as important transfer zones for upstream PP loads mainly via preferential flow pathways. This finds confirmation in the outcomes of tracer experiments conducted e.g. in France (van der Heijden et al., 2013) and in Germany (Julich et al., 2017), which have shown that phosphorus transport in forests occurs along preferential flow pathways, largely bypassing the nutrient-poor soil matrix of forests.

\subsection{Identified critical source areas}

The number of fields classified as a CSA, i.e. fields with a possibility of 0.5 or more, ranges from 1151 to 1233 for all the modelled scenarios. 14538 fields, on the other hand, are not classified as a CSA in any of the scenarios. This denotes an average of 1196 fields, which in relation to the total number of fields of 16320 constitutes a share of about $7.3 \%$. The differences in the number of CSAs can be regarded as negligible among the scenarios.

Furthermore, the median area of fields classified as a CSA in at least one scenario is $2.94 \times 10^{4} \mathrm{~m}^{2}$ with an interquartile range of $3.30 \times 10^{4}$ $\mathrm{m}^{2}$. The median area of fields never classified as a CSA is $0.74 \times 10^{4} \mathrm{~m}^{2}$ with an interquartile range of $1.31 \times 10^{4} \mathrm{~m}^{2}$. This considerable difference in the median field size and interquartile range explains the relative small share of fields regarded as CSAs compared to the approximately $20 \%$ of the total area of agricultural land under consideration.

A major reason for this percentage mismatch is the choice of the sum of all PP cell loads per field as input to the fuzzy large membership function, which favours the selection of comparatively large fields. The purpose of this choice is the maximisation of the anticipated decrease in PP emissions into surface waters per field due to the implementation of suitable mitigation measures and, at the same time, the minimisation of the number of farmers involved. While other choices like the average of all PP cell loads per field may offer a better overall potential costeffectiveness ratio, from a pragmatic perspective it would be likely more beneficial to have to convince fewer farmers to participate in a

\section{Table 2}

Selected percentiles of the sums of the PP cell loads per field of arable land in $\mathrm{kg}$ $\mathrm{yr}^{-1}$ for two selected scenarios.

\begin{tabular}{lllllllll}
\hline $\begin{array}{l}\text { Scenario/ } \\
\text { percentile }\end{array}$ & 0.30 & 0.50 & 0.70 & 0.90 & 0.92 & 0.94 & 0.96 & 0.98 \\
\hline $\begin{array}{c}\text { TC0.46-T1- } \\
\text { TOPO }\end{array}$ & 0.01 & 0.08 & 0.46 & 2.27 & 2.79 & 3.65 & 5.04 & 8.09 \\
$\begin{array}{c}\text { TC0.46-T6- } \\
\text { TOPO }\end{array}$ & 0.03 & 0.24 & 1.09 & 4.75 & 5.98 & 7.71 & 10.15 & 16.28 \\
\hline
\end{tabular}

catchment-wide water quality protection programme. With potential cost-effectiveness ratio, we here refer to the area of arable land taken out of production and thus associated with possible monetary compensations in order to reduce PP inputs into surface waters by a given amount.

The applied fuzzy large membership functions are designed to classify $20 \%$ of the total area of agricultural land as CSAs. Depending on the scenario, this share is responsible for $79-83 \%$ of the total PP inputs into surface waters, in line with the general 80:20 rule (Sharpley et al., 2009). Furthermore, apart from two outliers, all fields classified as a CSA in at least one of the scenarios (1782 fields) are arable fields. As a result, the $20 \%$ share of the total agricultural land classified as a CSA actually represents roughly $30 \%$ of the total arable land. This nonetheless underlines the general principle at work.

Table 3 shows the number of times as well as the cumulative share in which the same field is classified as a CSA. For the TC and T scenario groups, the shares of fields classified as a CSA in all of their respective scenarios lie, despite their different group sizes, around 50\%. For the flow direction scenario groups (TOPO, TILL and FURR), the same shares account for somewhat more than $60 \%$ of the fields. These differing shares can be explained by the fact that all flow directions and in turn flow accumulations are homogeneous within the flow direction scenario groups, but heterogeneous within the other scenario groups.

So-called UpSet plots allow for a rather easy to interpret visualization of multiple intersecting sets (Conway et al., 2017; Lex et al., 2014). Fig. 5 shows such a plot for a subset of the intersections of the CSAs of all T6 scenarios. All nine scenarios agree on 816 (46\%) of the in total 1782 fields, which are classified as a CSA at least once. Furthermore, there are 153 (96 plus 57; 9\%) CSA fields where the FURR scenario group makes a clear difference. This discrepancy emphasises the importance of knowing the relevant preferential flow pathways in a catchment under consideration. Another recognisable pattern is that the scenarios with lower transfer coefficients (especially TC0.32) differ slightly from those with higher transfer coefficients (TC0.46 and especially TC0.60). The T1 scenarios exhibit a similar pattern, albeit not as distinct as the one of the T6 scenarios.

Evenson et al. (2021) compared the use of five different watershed-scale models for the identification of CSAs of phosphorus emissions in the $17000 \mathrm{~km}^{2}$ Maumee River watershed. Their study reveals that on average only $16-46 \%$ of sub-watersheds were identified as CSAs by more than one model. This large disagreement is attributable to differences in input data, parametrisation and model structure. Based on these outcomes, Evenson et al. (2021) conclude that: (i) the share of watershed identified as CSAs by the different models can be selected for conservation measures with a high level of confidence; (ii) a comprehensive uncertainty analysis is essential in this field of research to enhance understanding and acceptance of modelling results by planners, decision makers and farmers.

All in all, our 18 scenarios perfectly agree on 720 of the 1782 fields classified as a CSA. This is a share of about $40 \%$. Therefore, similarly to the conclusion of Evenson et al. (2021), emission mitigation measures could concentrate on these areas with a high level of confidence. The remaining $60 \%$ of fields allocated as CSAs are diversely distributed among the various possible degrees of scenario intersections. Through the set-up of scenarios accounting for different sources of uncertainty, this study provides a transparent basis, which allows to understand which reasons lead to the different identification of CSAs. By merging the information of this screening as well as the uncertainty reasons with local knowledge of farmers and practitioners active on the territory, an optimal selection of fields could be achieved for the implementation of measures.

Including even more scenarios could push these two numbers even further apart, particularly, since each of the assessed scenario groups comes with its own limitations. A limitation of the transfer coefficient scenario group is for sure the choice of a global transfer coefficient. This assumption may not hold, as areas with higher flow accumulations may also exhibit higher transfer rates. Another limitation is that the presence 

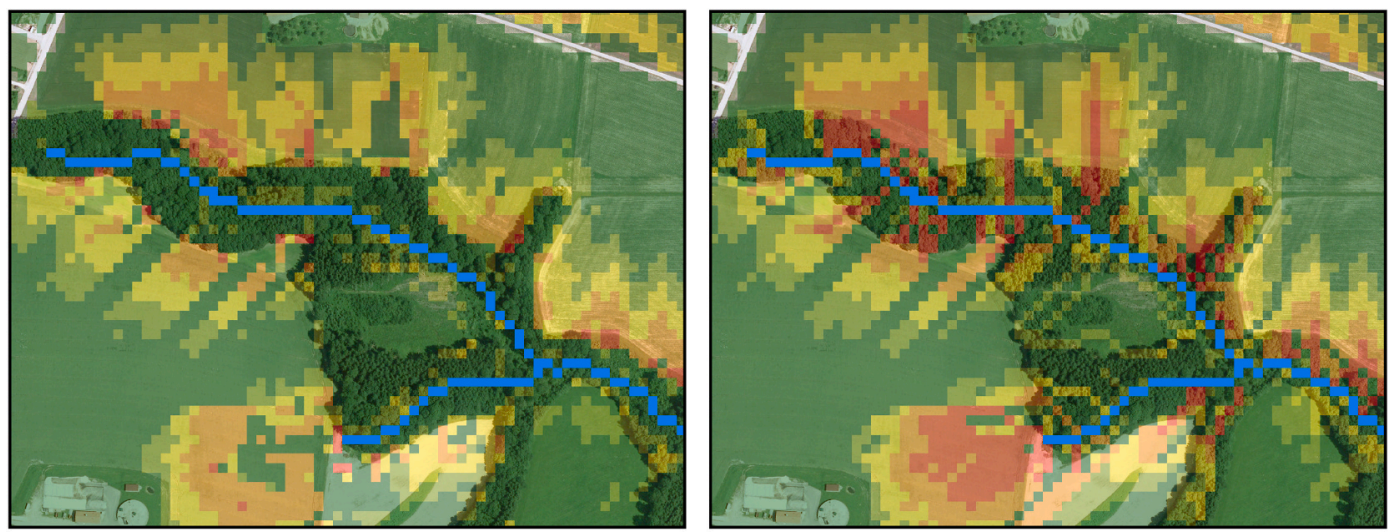

Channel cell

PP cell load/transfer in $\mathrm{kg} / \mathrm{yr}$
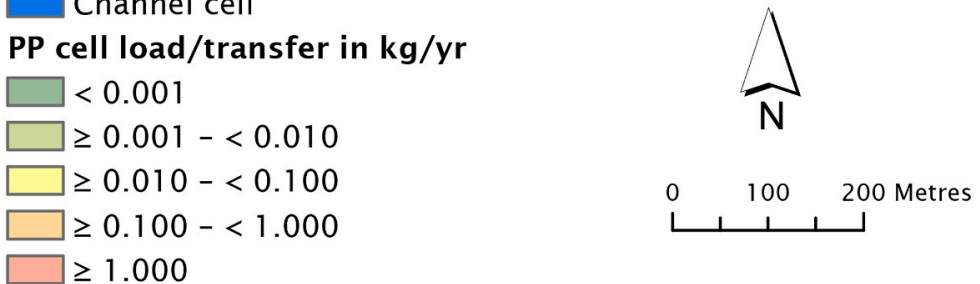

Fig. 4. Individual yearly PP cell loads (left) and transfers (right) of a small area within the case study catchment for the TC0.46-T6-TOPO scenario.

Table 3

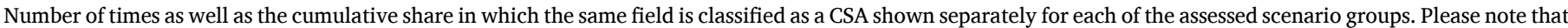

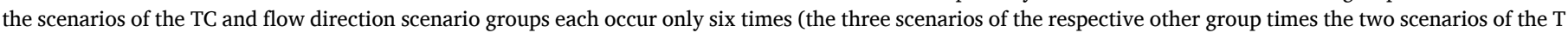

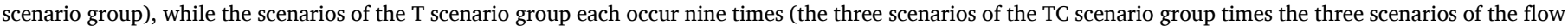
direction scenario group).

\begin{tabular}{|c|c|c|c|c|c|c|c|c|c|c|}
\hline Scenarios & 9 & 8 & 7 & 6 & 5 & 4 & 3 & 2 & 1 & 0 \\
\hline & \multicolumn{10}{|c|}{ No. of fields } \\
\hline TC0.32 & & & & 857 & 80 & 210 & 100 & 212 & 157 & 14704 \\
\hline TC0.46 & & & & 840 & 94 & 183 & 118 & 194 & 174 & 14717 \\
\hline TC0.60 & & & & 825 & 97 & 192 & 110 & 205 & 156 & 14735 \\
\hline $\mathrm{T} 1$ & 815 & 92 & 75 & 141 & 72 & 75 & 133 & 104 & 145 & 14668 \\
\hline $\mathrm{T} 6$ & 816 & 63 & 80 & 149 & 65 & 87 & 119 & 108 & 118 & 14715 \\
\hline TOPO & & & & 928 & 114 & 113 & 96 & 116 & 130 & 14823 \\
\hline TILL & & & & 927 & 121 & 108 & 100 & 108 & 139 & 14817 \\
\hline \multirow[t]{2}{*}{ FURR } & & & & 924 & 103 & 92 & 99 & 94 & 114 & 14894 \\
\hline & \multicolumn{10}{|c|}{ 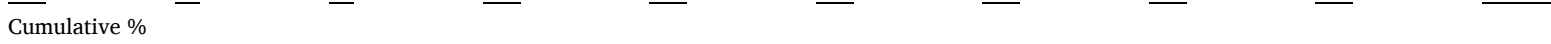 } \\
\hline TC0.32 & & & & 53 & 58 & 71 & 77 & 90 & 100 & \\
\hline TC0.46 & & & & 52 & 58 & 70 & 77 & 89 & 100 & \\
\hline TC0.60 & & & & 52 & 58 & 70 & 77 & 90 & 100 & \\
\hline $\mathrm{T} 1$ & 49 & 55 & 59 & 68 & 72 & 77 & 85 & 91 & 100 & \\
\hline $\mathrm{T} 6$ & 51 & 55 & 60 & 69 & 73 & 79 & 86 & 93 & 100 & \\
\hline TOPO & & & & 62 & 70 & 77 & 84 & 91 & 100 & \\
\hline TILL & & & & 62 & 70 & 77 & 84 & 91 & 100 & \\
\hline FURR & & & & 65 & 72 & 78 & 85 & 92 & 100 & \\
\hline
\end{tabular}

or absence as well as the exact location of individual storm drains remains uncertain (Hepp and Zessner, 2019).

While the erosion part of PhosFate based on the (R)USLE reflects average conditions, its transport part has to be adjusted to a specific discharge frequency. With longer periods both parts eventually represent average conditions. Especially the T1 scenarios exhibit a mismatch in this regard. Increasing the discharge frequency (e.g. from six to one year) yet has a similar effect as increasing the overland deposition rate. Since the latter acts as calibration and therefore as catch-all parameter for, among others, the effects of catchment elements, which cannot be represented by the chosen spatial resolution of $10 \times 10 \mathrm{~m}$, but where retention can take place (e.g. unploughed strips between fields, hedges), the former can be used as a proxy for studying the effects of the presence or absence of such elements. The global nature of such an increase in discharge frequency once more poses a severe limitation, as it mainly influences long-distance transport.

Finally, the limitations of the flow direction scenarios stem from limited knowledge on the actual tillage directions, surface roughness in and perpendicular to tillage directions and exact locations of open furrows capable of concentrating flow. Some or even all of these shortcomings may be remedied by better available data or improved methods to derive them from existing data in the future. Tillage directions, for example, could be more accurately derived for L-shaped fields from field border data encompassing every single cultivated crop and not only the outer border of all crops in direct vicinity, which are cultivated by the same farmer. The latter, unfortunately, applies in this case with the field borders currently available. 


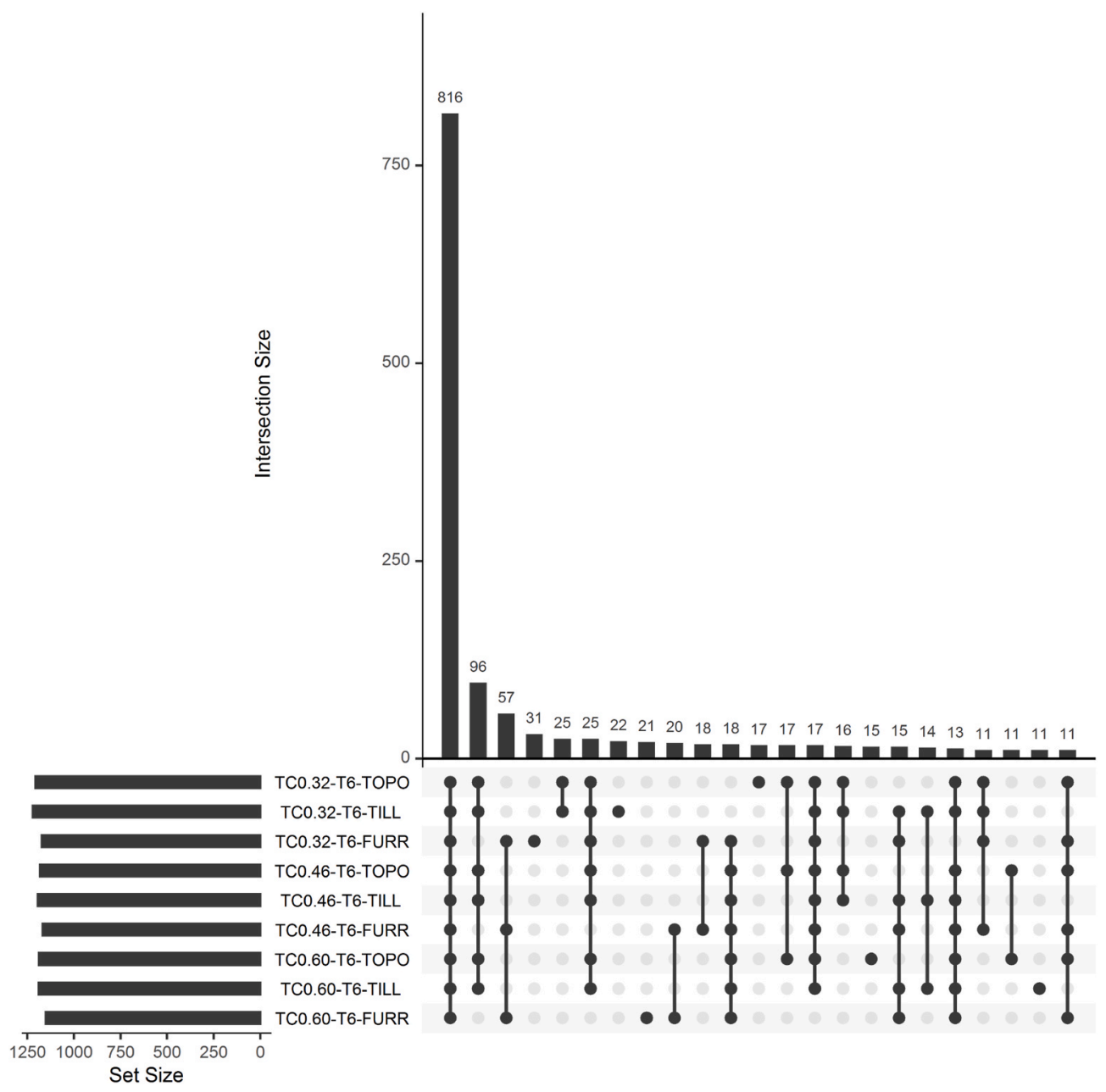

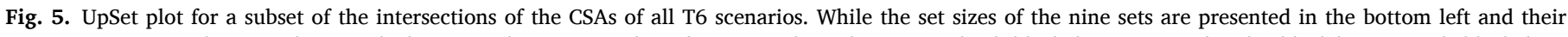

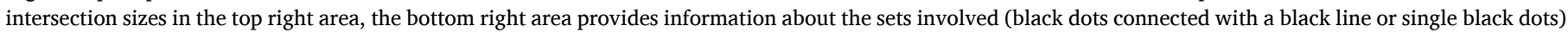
in each of the above displayed intersections.

\subsection{The final Particulate PhozzyLogic Index map}

Fig. 6 presents the final PPLI map of the case study catchment. The fields coloured violet can be considered the most possible CSAs. Most CSA fields are located near the catchment boundary, where the slopes are comparably higher, and in the northwest of the catchment. This map is the result of only a single option of overlaying multiple fuzzy sets. Further options, which should be tested in future research, are, for example, the application of different weights or other fuzzy overlay operators like the fuzzy gamma operator (Zimmermann and Zysno, 1980).

No matter how the different fuzzy sets are combined in the end, such a PPLI map can be a significant step forward in practice, since it allows each farmer to compare his or her fields to all the other fields within a certain catchment. This can be of great help when it comes to evaluating if - in the context of the entire catchment - a certain field substantially contributes to the overall PP emissions into surface waters or not. Furthermore, such a map provides a clear ranking for policy makers and could be used as a starting point for developing a state aid programme, which promotes the implementation of mitigation measures in a costeffective way. For this purpose, the height of subsidies could even be linked to the degree of possibility of a field being a CSA or not.

Such a map can thus foremost provide a detailed screening for the selection of the farmers to be involved in a programme of measures. Yet we consider it important that the final decision on the kind and exact location of the implemented mitigation measure stays with the farmer, as he or she has the best knowledge with respect to local details, which are not available for modelling. For example, in many cases only a small portion of vegetated buffer strips receives the majority of overland flow (Djodjic and Villa, 2015; White and Arnold, 2009), hence, the concept of CSAs can even be translated to a single field. Allowing farmers to choose from a variety of mitigation measures and combine them in a smart way may be capable of significantly improve the implementation quality and effectiveness.

Sharpley et al. (2011), while praising easy-to-use and well understandable colour-coded maps derived from P Indices, criticise their reliability and address the need of considering the spatial complexity of watersheds, the heterogeneous response time as well as delayed release of legacy PP, which eventually determine the expected effectiveness of measures on the long-term. The PPLI map presented here has the same traits praised by Sharpley et al. (2011) and conveys information in a straightforward and easily interpretable way, but at the same time it builds on a much more solid basis, namely on the results of a complex fate and transport model.

More recently, Wang et al. (2020) highlight in their review of modelling of phosphorus loss from field to watershed the strong need for integrating comprehensive uncertainty analyses in the studies to provide a more transparent and robust support to decision makers. Despite the above-mentioned limitations, the PPLI map based on the one hand on the outcomes of the PhosFate model and on the other hand on the overlay of several present-day scenario fuzzy sets, which take into account multiple sources of uncertainty, clearly meets the criteria of the 


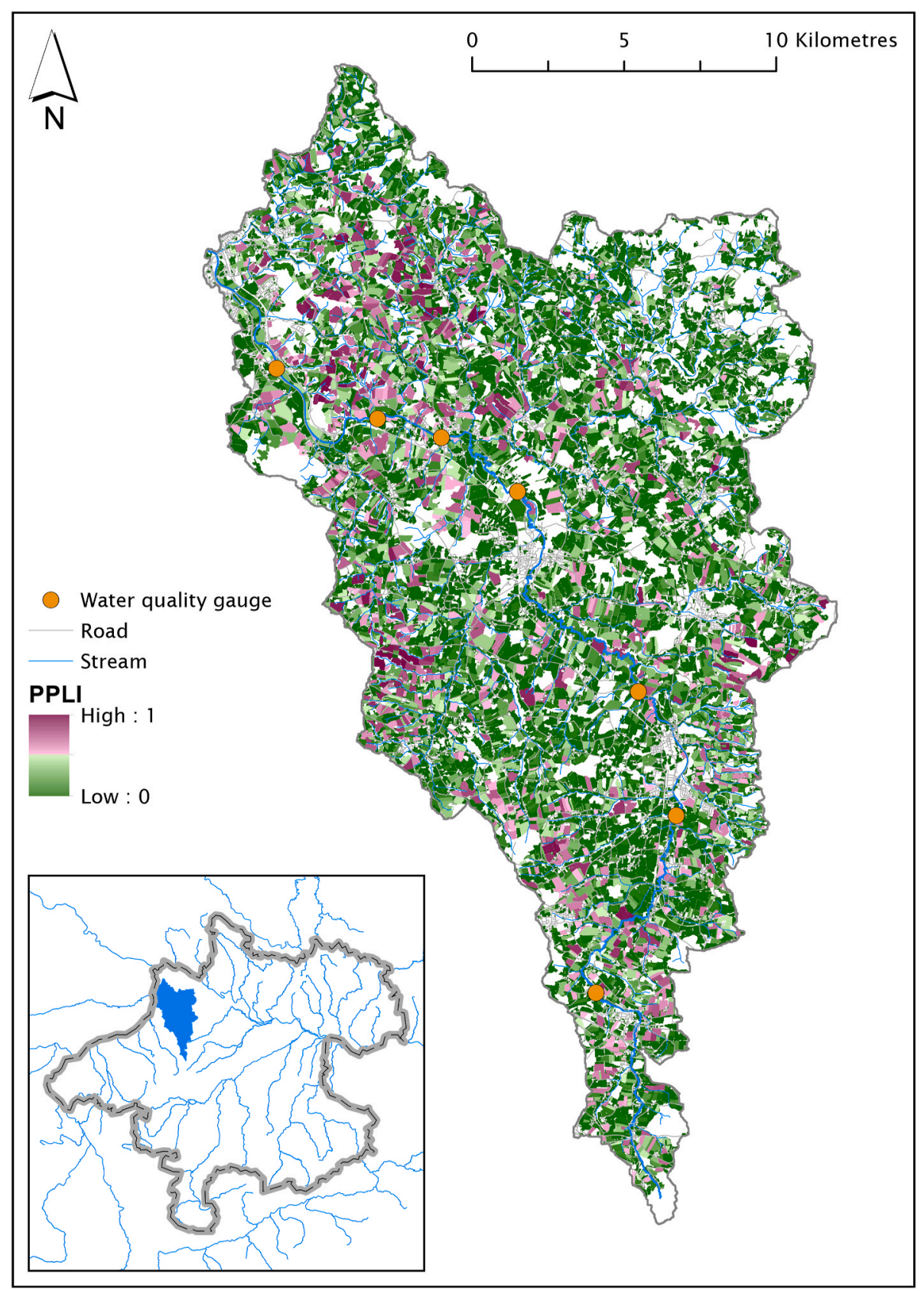

Fig. 6. Final PPLI map of the case study catchment: fields with an overall possibility of 0.5 or more, which can be considered the most possible CSAs, are coloured violet. A darker tone thereby indicates a higher possibility. (For interpretation of the references to colour in this figure legend, the reader is referred to the Web version of this article.)

advocated way forward in this field of research.

\section{Conclusions}

This study successfully developed a new algorithm for the allocation of PP emissions entering surface waters to their respective source areas. The algorithm was implemented into the existing semi-empirical, spatially distributed phosphorus emission and transport model called PhosFate. An innovative aspect of this algorithm is that in comparison to the existing one it does guarantee conservation of mass in every single cell and not only on the level of zero-order catchments.

With the help of fuzzy logic, it was then possible to translate these model results into a novel Phosphorus Index with a sound theoretical foundation in mathematics and a great value for management purposes. The novel Particulate PhozzyLogic Index (PPLI) ranks all agricultural fields of a potential large catchment with respect to their possibility of emitting high PP emissions actually reaching surface waters. Its range of possibility lies between zero ("not possible") and one ("perfectly possible"). Possibility values of 0.5 or higher imply that a field belongs to the $20 \%$ of agricultural land responsible for $80 \%$ of the PP inputs into surface waters, which is also our definition of CSAs.

The sensitivity analysis based on 18 scenarios shows that especially open furrows at field borders have the potential to cause deviating CSAs. A thorough validation of the identified CSAs within a catchment of several hundred square kilometres poses a major challenge and future research has to be carried out concerning the development of adequate validation strategies. While a validation strategy based on a representative sample of fields may be a conceivable option, an indirect strategy based on long-term measurements of PP concentrations in a representative sample of small sub-catchments may be a more viable yet also 
more approximative choice.

Another topic of future research should be the advancement of methods able to derive the positions of: (i) open furrows and other features capable of concentrating flow and (ii) agricultural and civil engineering structures (e.g. storm drains) acting as potential short cuts for surface run-off on its way to surface waters. In addition, a multi-flow version of the presented allocation algorithm, which is not only capable to model flow concentration, but also flow divergence may be a relevant topic for future research.

\section{Software availability}

The source code of the enhanced PhosFate model used in this study is available on GitHub in the form of an R package called RPhosFate.

\section{Credit author statement}

Gerold Hepp: Conceptualization, Methodology, Software, Formal analysis, Data Curation, Writing - Original Draft, Visualization. Ottavia Zoboli: Writing - Review \& Editing. Eva Strenge: Data Curation, Writing - Review \& Editing. Matthias Zessner: Conceptualization, Writing - Review \& Editing, Supervision, Project administration, Funding acquisition.

\section{Declaration of competing interest}

The authors declare that they have no known competing financial interests or personal relationships that could have appeared to influence the work reported in this paper.

\section{Acknowledgements}

This research was partly funded by the State Government of Upper Austria (contract number AUWR-2015-231 931/24-StU). The authors acknowledge TU Wien Bibliothek for financial support through its Open Access Funding Programme. Further, we especially thank Alain Couturier from the French National Institute of Agricultural Research (INRA) for providing us a copy of the STREAM model.

\section{References}

Alder, S., Prasuhn, V., Liniger, H., Herweg, K., Hurni, H., Candinas, A., Gujer, H.U., 2015. A high-resolution map of direct and indirect connectivity of erosion risk areas to surface waters in Switzerland-a risk assessment tool for planning and policymaking. Land Use Pol. 48, 236-249. https://doi.org/10.1016/j. landusepol.2015.06.001.

BMLFUW, 2015. Hydrografisches Jahrbuch von Österreich 2013. Daten und Auswertungen. Technical Report 121. Bundesministerium für Land- und Forstwirtschaft, Umwelt und Wasserwirtschaft (Wien).

Buczko, U., Kuchenbuch, R.O., 2007. Phosphorus indices as risk-assessment tools in the U.S.A. and Europe-a review. J. Plant Nutr. Soil Sci. 170, 445-460. https://doi.org/ 10.1002/jpln.200725134.

Bug, J.F., 2011. Modellierung der linearen Erosion und des Risikos von Partikeleinträgen in Gewässer. Ph.D. thesis. Leibniz Universität Hannover, Hannover.

Cerdan, O., Bissonnais, Y.L., Souchère, V., Martin, P., Lecomte, V., 2002a. Sediment concentration in interrill flow: Interactions between soil surface conditions, vegetation and rainfall. Earth Surf. Process. Landforms 27, 193-205. https://doi. org/10.1002/esp.314.

Cerdan, O., Souchère, V., Lecomte, V., Couturier, A., Le Bissonnais, Y., 2002b. Incorporating soil surface crusting processes in an expert-based runoff model: Sealing and Transfer by Runoff and Erosion related to Agricultural Management. CATENA 46, 189-205. https://doi.org/10.1016/S0341-8162(01)00166-7.

Champati ray, P.K., Dimri, S., Lakhera, R.C., Sati, S., 2007. Fuzzy-based method for landslide hazard assessment in active seismic zone of Himalaya. Landslides 4, 101. https://doi.org/10.1007/s10346-006-0068-6.

Charnpratheep, K., Zhou, Q., Garner, B., 1997. Preliminary landfill site screening using fuzzy geographical information systems. Waste Manag. Res. 15, 197-215. https:// doi.org/10.1006/wmre.1996.0076.

Cherry, K.A., Shepherd, M., Withers, P.J.A., Mooney, S.J., 2008. Assessing the effectiveness of actions to mitigate nutrient loss from agriculture: A review of methods. Sci. Total Environ. 406, 1-23. https://doi.org/10.1016/j. scitotenv.2008.07.015.
Conway, J.R., Lex, A., Gehlenborg, N., 2017. UpSetR: An R package for the visualization of intersecting sets and their properties. Bioinformatics 33, 2938-2940. https://doi. org/10.1093/bioinformatics/btx364.

Couturier, A., Daroussin, J., Darboux, F., Souchère, V., Le Bissonnais, Y., Cerdan, O., King, D., 2013. Improvement of surface flow network prediction for the modeling of erosion processes in agricultural landscapes. Geomorphology 183, 120-129. https:// doi.org/10.1016/j.geomorph.2012.07.025.

Desmet, P.J.J., Govers, G., 1996. A GIS procedure for automatically calculating the USLE LS factor on topographically complex landscape units. J. Soil Water Conserv. 51, 427-433.

Djodjic, F., Villa, A., 2015. Distributed, high-resolution modelling of critical source areas for erosion and phosphorus losses. Ambio 44, 241-251. https://doi.org/10.1007/ s13280-014-0618-4.

Doppler, T., Camenzuli, L., Hirzel, G., Krauss, M., Lück, A., Stamm, C., 2012. Spatial variability of herbicide mobilisation and transport at catchment scale: Insights from a field experiment. Hydrol. Earth Syst. Sci. 16, 1947-1967. https://doi.org/ 10.5194/hess-16-1947-2012.

Dubois, D., Prade, H., 1985. A review of fuzzy set aggregation connectives. Inf. Sci. 36, 85-121. https://doi.org/10.1016/0020-0255(85)90027-1.

Engman, E.T., 1986. Roughness coefficients for routing surface runoff. J. Irrigat. Drain. Eng. 112, 39-53.

European Comission, 2000. Directive 2000/60/EC of the European Parliament and of the Council of 23 October 2000 Establishing a Framework for Community Action in the Field of Water Policy.

Evenson, G.R., Kalcic, M., Wang, Y.C., Robertson, D., Scavia, D., Martin, J., Aloysius, N., Apostel, A., Boles, C., Brooker, M., Confesor, R., Dagnew, A.T., Guo, T., Kast, J., Kujawa, H., Muenich, R.L., Murumkar, A., Redder, T., 2021. Uncertainty in critical source area predictions from watershed-scale hydrologic models. J. Environ. Manag. 279, 111506. https://doi.org/10.1016/j.jenvman.2020.111506.

Gburek, W.J., Sharpley, A.N., Heathwaite, L., Folmar, G.J., 2000. Phosphorus management at the watershed scale: A modification of the phosphorus index. J. Environ. Qual. 29, 130-144. https://doi.org/10.2134/ jeq2000.00472425002900010017x.

Geoland.at, 2016. Intermodales Verkehrsreferenzsystem Österreich (GIP.at). Technical Report. Geodatenverbund der Länder, Wien.

Ghebremichael, L.T., Veith, T.L., Hamlett, J.M., 2013. Integrated watershed- and farmscale modeling framework for targeting critical source areas while maintaining farm economic viability. J. Environ. Manag. 114, 381-394. https://doi.org/10.1016/j. jenvman.2012.10.034.

Heathwaite, A.L., Quinn, P.F., Hewett, C.J.M., 2005. Modelling and managing critical source areas of diffuse pollution from agricultural land using flow connectivity simulation. J. Hydrol. 304, 446-461. https://doi.org/10.1016/j. jhydrol.2004.07.043.

Heathwaite, L., Sharpley, A., Bechmann, M., 2003. The conceptual basis for a decision support framework to assess the risk of phosphorus loss at the field scale across Europe. J. Plant Nutr. Soil Sci. 166, 447-458. https://doi.org/10.1002/ jpln.200321154.

Hepp, G., Zessner, M., 2019. Assessing the impact of storm drains at road embankments on diffuse particulate phosphorus emissions in agricultural catchments. Water 11, 2161. https://doi.org/10.3390/w11102161.

Hofer, O., Fahrner, W., Pavlis-Fronaschitz, G., Linder, S., Gmeiner, P., 2014. INVEKOSDatenpool 2014 des BMLFUW. Übersicht über alle im Ordner ,Invekosdaten“ enthaltenen Datenbanken mit ausführlicher Tabellenbeschreibung sowie Informationen zu sonstigen verfügbaren Datenbanken. Technical Report. Bundesministerium für Land- und Forstwirtschaft, Umwelt und Wasserwirtschaft (Wien).

Julich, D., Julich, S., Feger, K.H., 2017. Phosphorus in preferential flow pathways of forest soils in germany. Forests 8, 19. https://doi.org/10.3390/f8010019.

Kandel, A., 1986. Fuzzy Mathematical Techniques with Applications. Addison-Wesley, Reading.

Kovacs, A., 2013. Quantification of Diffuse Phosphorous Inputs into Surface Water Systems. Technische Universität Wien, Vienna. Ph.D. thesis.

Kovacs, A., Honti, M., Zessner, M., Eder, A., Clement, A., Blöschl, G., 2012. Identification of phosphorus emission hotspots in agricultural catchments. Sci. Total Environ. 433, 74-88. https://doi.org/10.1016/j.scitotenv.2012.06.024.

Kovacs, A.S., Honti, M., Clement, A., 2008. Design of best management practice applications for diffuse phosphorus pollution using interactive GIS. Water Sci. Technol. 57, 1727-1733. https://doi.org/10.2166/wst.2008.264.

Krause, P., Boyle, D.P., Bäse, F., 2005. Comparison of different efficiency criteria for hydrological model assessment. Adv. Geosci. 5, 89-97.

Le Bissonnais, Y., Cerdan, O., Lecomte, V., Benkhadra, H., Souchère, V., Martin, P., 2005. Variability of soil surface characteristics influencing runoff and interrill erosion. CATENA 62, 111-124. https://doi.org/10.1016/j.catena.2005.05.001.

Lemunyon, J.L., Gilbert, R.G., 1993. The concept and need for a phosphorus assessment tool. J. Prod. Agric. 6, 483-486. https://doi.org/10.2134/jpa1993.0483.

Lermontov, A., Yokoyama, L., Lermontov, M., Machado, M.A.S., 2009. River quality analysis using fuzzy water quality index: Ribeira do Iguape river watershed, Brazil. Ecol. Indicat. 9, 1188-1197. https://doi.org/10.1016/j.ecolind.2009.02.006.

Lex, A., Gehlenborg, N., Strobelt, H., Vuillemot, R., Pfister, H., 2014. UpSet: Visualization of intersecting sets. IEEE Trans. Visual. Comput. Graph. 20, 1983-1992. https://doi. org/10.1109/TVCG.2014.2346248.

Liou, S.M., Lo, S.L., Hu, C.Y., 2003. Application of two-stage fuzzy set theory to river quality evaluation in Taiwan. Water Res. 37, 1406-1416. https://doi.org/10.1016/ s0043-1354(02)00479-7. 
Liu, Y.B., De Smedt, F., 2004. WetSpa Extension, a GIS-Based Hydrologic Model for Flood Prediction and Watershed Management. Technical Report. Department of Hydrology and Hydraulic Engineering of the Vrije Universiteit Brussel, Brussels.

Mallarino, A.P., Stewart, B.M., Baker, J.L., Downing, J.D., Sawyer, J.E., 2002. Phosphorus indexing for cropland: Overview and basic concepts of the iowa phosphorus index. J. Soil Water Conserv. 57, 440-447.

Martin-Ortega, J., Balana, B.B., 2012. Cost-effectiveness analysis in the implementation of the Water Framework Directive: A comparative analysis of the United Kingdom and Spain. Eur. Water 37, 15-25.

Molnár, P., Ramírez, J.A., 1998. Energy dissipation theories and optimal channel characteristics of river networks. Water Resour. Res. 34, 1809-1818. https://doi. org/10.1029/98WR00983.

Moriasi, D.N., Arnold, J.G., Van Liew, M.W., Bingner, R.L., Harmel, R.D., Veith, T.L., 2007. Model evaluation guidelines for systematic quantification of accuracy in watershed simulations. Trans. ASABE (Am. Soc. Agric. Biol. Eng.) 50, 885-900.

Nash, J.E., Sutcliffe, J.V., 1970. River flow forecasting through conceptual models part I - a discussion of principles. J. Hydrol. 10, 282-290. https://doi.org/10.1016/00221694(70)90255-6.

Onnen, N., Heckrath, G., Stevens, A., Olsen, P., Greve, M.B., Pullens, J.W.M., Kronvang, B., Van Oost, K., 2019. Distributed water erosion modelling at fine spatial resolution across Denmark. Geomorphology 342, 150-162. https://doi.org/ 10.1016/j.geomorph.2019.06.011.

Pionke, H.B., Gburek, W.J., Sharpley, A.N., 2000. Critical source area controls on water quality in an agricultural watershed located in the Chesapeake Basin. Ecol. Eng. 14, 325-335. https://doi.org/10.1016/S0925-8574(99)00059-2.

Poesen, J., 2018. Soil erosion in the Anthropocene: Research needs. Earth Surf. Process. Landforms 43, 64-84. https://doi.org/10.1002/esp.4250.

Pourghasemi, H.R., Pradhan, B., Gokceoglu, C., 2012. Application of fuzzy logic and analytical hierarchy process (AHP) to landslide susceptibility mapping at Haraz watershed, Iran. Nat. Hazards 63, 965-996. https://doi.org/10.1007/s11069-0120217-2.

Prasuhn, V., 2011. Soil erosion in the Swiss midlands: Results of a 10-year field survey. Geomorphology 126, 32-41. https://doi.org/10.1016/j.geomorph.2010.10.023.

Rebolledo, B., Gil, A., Flotats, X., Sánchez, J.Á., 2016. Assessment of groundwater vulnerability to nitrates from agricultural sources using a GIS-compatible logic multicriteria model. J. Environ. Manag. 171, 70-80. https://doi.org/10.1016/j. jenvman.2016.01.041.

Remund, D., Liebisch, F., Liniger, H.P., Heinimann, A., Prasuhn, V., 2021. The origin of sediment and particulate phosphorus inputs into water bodies in the Swiss Midlands - a twenty-year field study of soil erosion. CATENA 203, 105290. https://doi.org/ 10.1016/j.catena.2021.105290.

Renard, K.G., Foster, G.R., Weesies, G.A., McCool, D.K., Yoder, D.C., 1997. Predicting Soil Erosion by Water: A Guide to Conservation Planning with the Revised Universal Soil Loss Equation (RUSLE). Number 703 in Agriculture Handbook. U.S. Government Printing Office, Washington, DC.

Robinson, V.B., 2003. A perspective on the fundamentals of fuzzy sets and their use in geographic information systems. Trans. GIS 7, 3-30. https://doi.org/10.1111/1467 9671.00127.

Schwertmann, U., Vogl, W., Kainz, M., 1987. Bodenerosion durch Wasser. Vorhersage des Abtrags und Bewertung von Gegenmaßnahmen, second ed. Ulmer, Stuttgart.

Sharpley, A.N., Kleinman, P.J.A., Flaten, D.N., Buda, A.R., 2011. Critical source area management of agricultural phosphorus: Experiences, challenges and opportunities. Water Sci. Technol. 64, 945-952. https://doi.org/10.2166/wst.2011.712.

Sharpley, A.N., Kleinman, P.J.A., Jordan, P., Bergström, L., Allen, A.L., 2009. Evaluating the success of phosphorus management from field to watershed. J. Environ. Qual. 38, 1981-1988. https://doi.org/10.2134/jeq2008.0056.

Sims, J.T., Sharpley, A.N., 2005. Phosphorus: Agriculture and the environment. Phosphorus Agric. Environ.

Souchere, V., King, D., Daroussin, J., Papy, F., Capillon, A., 1998. Effects of tillage on runoff directions: Consequences on runoff contributing area within agricultural catchments. J. Hydrol. 206, 256-267. https://doi.org/10.1016/S0022-1694(98) 00103-6.

Strauss, P., Leone, A., Ripa, M.N., Turpin, N., Lescot, J.M., Laplana, R., 2007. Using critical source areas for targeting cost-effective best management practices to mitigate phosphorus and sediment transfer at the watershed scale. Soil Use Manag. 23, 144-153. https://doi.org/10.1111/j.1475-2743.2007.00118.x.

Takken, I., Govers, G., Jetten, V., Nachtergaele, J., Steegen, A., Poesen, J., 2001a. Effects of tillage on runoff and erosion patterns. Soil Tillage Res. 61, 55-60. https://doi.org/ 10.1016/S0167-1987(01)00178-7.
Takken, I., Govers, G., Steegen, A., Nachtergaele, J., Guérif, J., 2001b. The prediction of runoff flow directions on tilled fields. J. Hydrol. 248, 1-13. https://doi.org/ 10.1016/S0022-1694(01)00360-2.

Takken, I., Jetten, V., Govers, G., Nachtergaele, J., Steegen, A., 2001c. The effect of tillage-induced roughness on runoff and erosion patterns. Geomorphology 37, 1-14. https://doi.org/10.1016/S0169-555X(00)00059-3.

Tien Bui, D., Pradhan, B., Lofman, O., Revhaug, I., Dick, O.B., 2012. Spatial prediction of landslide hazards in Hoa Binh province (Vietnam): A comparative assessment of the efficacy of evidential belief functions and fuzzy logic models. CATENA 96, 28-40. https://doi.org/10.1016/j.catena.2012.04.001.

Tiessen, H., 2008. Phosphorus in the global environment. In: White, P.J., Hammond, J.P. (Eds.), The Ecophysiology of Plant-Phosphorus Interactions. Springer Netherlands, Dordrecht, pp. 1-7. https://doi.org/10.1007/978-1-4020-8435-5_1. Plant Ecophysiology.

Vadiati, M., Asghari-Moghaddam, A., Nakhaei, M., Adamowski, J., Akbarzadeh, A.H., 2016. A fuzzy-logic based decision-making approach for identification of groundwater quality based on groundwater quality indices. J. Environ. Manag. 184, 255-270. https://doi.org/10.1016/j.jenvman.2016.09.082.

van der Heijden, G., Legout, A., Pollier, B., Bréchet, C., Ranger, J., Dambrine, E., 2013. Tracing and modeling preferential flow in a forest soil—potential impact on nutrient leaching. Geoderma 195-196, 12-22. https://doi.org/10.1016/j. geoderma.2012.11.004.

Van Oost, K., Govers, G., Desmet, P., 2000. Evaluating the effects of changes in landscape structure on soil erosion by water and tillage. Landsc. Ecol. 15, 577-589. https://doi. org/10.1023/A:1008198215674.

Van Rompaey, A.J.J., Verstraeten, G., Van Oost, K., Govers, G., Poesen, J., 2001. Modelling mean annual sediment yield using a distributed approach. Earth Surf. Process. Landforms 26, 1221-1236. https://doi.org/10.1002/esp.275.

Verstraeten, G., Van Oost, K., Van Rompaey, A., Poesen, J., Govers, G., 2002. Evaluating an integrated approach to catchment management to reduce soil loss and sediment pollution through modelling. Soil Use Manag. 18, 386-394. https://doi.org/ 10.1111/j.1475-2743.2002.tb00257.x.

Wang, Z., Zhang, T., Tan, C.S., Qi, Z., 2020. Modeling of phosphorus loss from field to watershed: A review. J. Environ. Qual. 49, 1203-1224. https://doi.org/10.1002/ jeq2.20109.

White, M.J., Arnold, J.G., 2009. Development of a simplistic vegetative filter strip model for sediment and nutrient retention at the field scale. Hydrol. Process. 23, 1602-1616. https://doi.org/10.1002/hyp.7291.

White, M.J., Storm, D.E., Busteed, P.R., Stoodley, S.H., Phillips, S.J., 2009. Evaluating nonpoint source critical source area contributions at the watershed scale. J. Environ. Qual. 38, 1654-1663. https://doi.org/10.2134/jeq2008.0375.

Wischmeier, W.H., Smith, D.D., 1978. Predicting Rainfall Erosion Losses. A Guide to Conservation Planning. Number 537 in Agriculture Handbook. U.S. Government Printing Office, Washington, DC.

Zadeh, L.A., 1965. Fuzzy sets. Inf. Control 8, 338-353. https://doi.org/10.1016/S00199958(65) $90241-X$.

Zadeh, L.A., 1978. Fuzzy sets as a basis for a theory of possibility. Fuzzy Set Syst. 1, 3-28.

Zessner, M., Gabriel, O., Kovacs, A., Kuderna, M., Schilling, C., Hochedlinger, G., Windhofer, G., 2011. Analyse der Nährstoffströme in oberösterreichischen Einzugsgebieten nach unterschiedlichen Eintragspfaden für strategische Planungen (Nährstoffströme Oberösterreich). Technical Report. Amt der Oberösterreichischen Landesregierung, Wien.

Zessner, M., Hepp, G., Kuderna, M., Weinberger, C., Gabriel, O., 2017. Zustandserfassung, Nährstoffentwicklung und Quantifizierung der Maßnahmenwirksamkeiten von ÖPUL 2007 in oberösterreichischen Einzugsgebieten. Technical Report. Amt der Oberösterreichischen Landesregierung, Wien.

Zessner, M., Hepp, G., Zoboli, O., Mollo Manonelles, O., Kuderna, M., Weinberger, C., Gabriel, O., 2016a. Erstellung und Evaluierung eines Prognosetools zur Quantifizierung von Maßnahmenwirksamkeiten im Bereich der Nährstoffeinträge in oberösterreichische Oberflächengewässer. Technical Report. Amt der Oberösterreichischen Landesregierung, Wien.

Zessner, M., Zoboli, O., Hepp, G., Kuderna, M., Weinberger, C., Gabriel, O., 2016b. Shedding light on increasing trends of phosphorus concentration in Upper Austrian rivers. Water 8, 404. https://doi.org/10.3390/w8090404.

Zimmermann, H.J., Zysno, P., 1980. Latent connectives in human decision making. Fuzzy Set Syst. 4, 37-51. https://doi.org/10.1016/0165-0114(80)90062-7.

Zoboli, O., Viglione, A., Rechberger, H., Zessner, M., 2015. Impact of reduced anthropogenic emissions and century flood on the phosphorus stock, concentrations and loads in the Upper Danube. Sci. Total Environ. 518-519, 117-129. https://doi. org/10.1016/j.scitotenv.2015.02.087. 